\title{
Effects of Calcification Inhibitors on the Viability of the Coralline Algae Lithophyllum yessoense and Corallina pilulifera
}

\author{
Ji-Young Kang ${ }^{1}$, Ji-Young Choi ${ }^{1}$, Jin $\mathrm{Joo}^{2}$, Yoo Seong Choi ${ }^{3}$, Dong Soo Hwang ${ }^{4}$, Ji-Young Cho ${ }^{5}$ and \\ Yong-Ki Hong ${ }^{1 *}$ \\ ${ }^{1}$ Department of Biotechnology, Pukyong National University, Busan 608-737, Korea \\ ${ }^{2}$ Department of Applied Chemistry, Kyungpook National University, Daegu 702-701, Korea \\ ${ }^{3}$ Department of Chemical Engineering, Chungnam National University, Daejeon 305-764, Korea \\ ${ }^{4}$ Postech Ocean Science \& Technology Institute, Pohang University of Science \& Technology, Pohang 790-784, Korea \\ ${ }^{5}$ Department of Marine Biotechnology, Soonchunhyang University, Asan 336-900, Korea
}

\begin{abstract}
Coralline algae, the algal whitening phenomenon-causing seaweeds, are characterized by calcareous deposits in the cell wall. The viability of the coralline algae Lithophyllum yessoense and Corallina pilulifera was quantitated using a triphenyltetrazolium chloride assay and eight calcification inhibitors. Among these inhibitors, ferric citrate showed the strongest inhibition of coralline algae viability. The concentrations of ferric citrate conferring 50\% inhibition were 1.7 and $3.8 \mathrm{mM}$ for L. yessoense and C. pilulifera, respectively. Thus, at a specific concentration and in a localized area, ferric citrate may be used to prevent the blooming of coralline algae.
\end{abstract}

Key words: Algal whitening, Anti-fouling, Calcification inhibitor, Ferric citrate, Lithophyllum yessoense, Corallina pilulifera

\section{Introduction}

Many rocky seashore areas of Korea and Japan are dominated by coralline algae such as Lithophyllum yessoense ( $\mathrm{Su}-$ zuki et al., 1998; Kim, 2000). However, as calcareous algae cover the surfaces of rocks in a pink-colored crust, the area covered by seaweed flora decreases. This algal whitening phenomenon is observed in barren ground, coralline flats, and deforested areas, and is associated with specific species of coralline algae (Tokuda et al., 1994). Since 1990, the area affected by algal whitening, which runs from south Cheju Island to the middle East Sea, has expanded (Chung et al., 1998). In this area, most of the fleshy seaweed has disappeared from the rocks because of algal whitening, which reduces food sources and spawning locations for fish and shellfish. This phenomenon is now considered a natural hazard adversely affecting marine ecosystems and damaging commercial fishing areas. Although biological (Agateuma et al., 1997; Daume et al., 1999) and physical (Masaki et al., 1984; Johnson and Mann, 1986) factors may be sufficient to prevent the recruitment of fleshy seaweeds, allelopathic bromoform (Ohsawa et al., 2001) and fatty acid (Kim et al., 2004; Luyen et al., 2009) substances inhibit the settlement or germination of seaweed spores. One approach to restore fleshy seaweed colonization in these areas is the removal or inhibition of living coralline algae. Before applying chemicals in the field, it is necessary to test the in vitro inhibitory activity of several calcification inhibitors against coralline algae to identify compounds suitable for coralline species inhibition in areas affected by algal whitening. Alternatively, coralline algae may be used to pre-
(C) 2014 The Korean Society of Fisheries and Aquatic Science This is an Open Access article distributed under the terms of the Creative Commons Attribution Non-Commercial Licens (http://creativecommons. org/licenses/by-nc/3.0/) which permits unrestricted non-commercial use, distribution, and reproduction in any medium, provided the original work is properly cited.
Received 11 December 2013; Revised 09 February 2014

Accepted 10 February 2014

*Corresponding Author

E-mail: ykhong@pknu.ac.kr 
vent fouling by fleshy seaweeds. When a biomimetic coralline algal material is prepared, it can be used as an environmentally friendly anti-fouling material. To generate biomimetic coralline material, it is necessary to add a calcification inhibitor to the material to prevent additional attachment and the blooming of living coralline algae on the product. Thus, a calcification inhibitor can be used to remediate algal whitening and prepare a biomimetic coralline material. In this report, inhibitors were quantitatively screened using a triphenyltetrazolium chloride (TTC) assay.

\section{Materials and Methods}

\section{Tissue preparation}

The coralline algae L. yessoense and Corallina pilulifera were collected from the rocky intertidal area at Cheongsapo $\left(35^{\circ} 09^{\prime} 28^{\prime \prime} \mathrm{N}, 129^{\circ} 11^{\prime} 47^{\prime \prime} \mathrm{E}\right)$, on the east coast of Busan, Korea. Stones covered with coralline algae were transported in a container of seawater to the laboratory. After rinsing well with autoclaved seawater to remove epiphytes and debris, the encrusted or non-articulated tissues of L. yessoense were sonicated three times with 30 -s pulses of an ultrasonic water bath (low-intensity frequency of $40 \mathrm{kHz}$ ) to remove other microepiphytes. The tissue was then scraped off the stones using a saw and thoroughly washed at least six times by centrifugation at $1,000 \mathrm{~g}$ for $30 \mathrm{~s}$ (Kang et al., 2005). Articulated coralline tissues were cleaned by brushing thoroughly and sonicating (40 kHz) twice for $1 \mathrm{~min}$ in autoclaved seawater, and then immersed in $1 \%$ Betadine for 2 min to eliminate epiphytes (Jin et al., 1997). The articulated coralline tissues were then rehabilitated at $18^{\circ} \mathrm{C}$ in Provasoli's enriched seawater (PES) (Provasoli, 1968) for 1 day before use.

\section{Tissue culture}

In the tissue cultures of coralline algae, six hydroxyapatite inhibitors (alendronate sodium trihydrate, $\mathrm{AlCl}_{3}$, dichloromethylene diphosphonic acid, etidronic acid, ferric citrate, and $\mathrm{FeCl}_{3}$ ) and one bicarbonate channel blocker (4,4'-diisothiocyanatostilbene-2,2' -disulfonic acid) as calcium inhibitors were dissolved in distilled water and added to the tissue culture solution at concentrations of 10 or $1 \mathrm{mM}$, respectively. In addition, an impermeable carbonic anhydrase inhibitor (acetazolamide) was dissolved in dimethyl sulfoxide (DMSO) and added to the solution. To measure tissue viability, $25 \mu \mathrm{L}$ of each inhibitor was added to $5 \mathrm{~mL}$ of PES medium containing $0.1 \mathrm{~g}$ of $L$. yessoense or $0.05 \mathrm{~g}$ of $C$. pilulifera. The mixture was cultured for 5 days at $16^{\circ} \mathrm{C}$ with rotation at 20 rpm under a photon flux density (fluorescent light) of $40 \mu \mathrm{mol}$ $\mathrm{m}^{-2} \mathrm{~s}^{-1}$ and on a light cycle of $16-\mathrm{h}$ light/8-h dark. A reference culture was prepared by mixing $25 \mu \mathrm{L}$ of distilled water or DMSO in the same medium. After harvesting the tissues by centrifugation at 3,000 $\mathrm{g}$ for $30 \mathrm{~s}$, cell viability was measured using the TTC assay. The relative viability (\%) was calculated as: $(\mathrm{S} / \mathrm{C}) \times 100$, where $\mathrm{S}$ equals the absorbance of the tissue with inhibitors and $\mathrm{C}$ equals the absorbance of the reference culture.

\section{Viability assay}

The TTC assay described by Park et al. (2006) was used. A total of $1 \mathrm{~mL}$ of $0.8 \%$ TTC solution in seawater containing $50 \mathrm{mM}$ Tris- $\mathrm{HCl}$ buffer ( $\mathrm{pH} 8.0$ ) was added to the tissue in a microtube and incubated in the dark for $1.5 \mathrm{~h}$ at $20^{\circ} \mathrm{C}$ under a drop of mineral oil (M-3516; Sigma, St. Louis, MO, USA). The tissue was then rinsed four times by centrifugation at 3,000 $\mathrm{g}$ for $30 \mathrm{~s}$ with sterilized seawater. Triphenylformazan (TPF) that formed in the tissues was extracted with 0.6 $\mathrm{mL}$ of $0.2 \mathrm{~N} \mathrm{NaOH}$ in $75 \%$ ethanol by heating for $15 \mathrm{~min}$ at $60^{\circ} \mathrm{C}$. Next, TPF was partitioned by adding $0.6 \mathrm{~mL}$ of hexane followed by vortexing. After centrifugation for $1 \mathrm{~min}$, the amount of TPF from the top phase was quantified by measuring the absorbance at $475 \mathrm{~nm}$.

\section{Statistical analysis}

For each assay with calcification inhibitors and control samples, the experiments were repeated at least three times. The mean values of the index were compared to the control using Student's $t$-test.

\section{Results}

To determine the effects of the calcification inhibitors on coralline viability, we compared eight commercially available inhibitors, including six hydroxyapatite inhibitors, one bicarbonate channel blocker, and one carbonic anhydrase inhibitor. Each compound at 1 and $10 \mathrm{mM}$, respectively, was added to the coralline culture, and the viability of the culture after 5 days was measured using the TTC assay. For crustose $L$. yessoense tissues, reference cultures without calcification inhibitors reached an absorbance of 1.24. Ferric citrate showed an absorbance of 0.02 , which corresponded to $2 \%$ relative viability at $10 \mathrm{mM}$ (Table 1). At $1 \mathrm{mM}$, ferric citrate inhibited viability to $76 \%$ compared to the control. Next, $\mathrm{FeCl}_{2}$ inhibited viability to $54 \%$ at $10 \mathrm{mM}$. The effects of the calcification inhibitors on the viability of articulated coralline $C$. pilulifera were also determined using the TTC assay after 5 days of culture. A reference culture lacking calcification inhibitors reached an absorbance of 1.11. Among the inhibitors, ferric citrate, $\mathrm{AlCl}_{3}$, and $\mathrm{FeCl}_{3}$ inhibited viability to $15 \%, 20 \%$, and $29 \%$ compared to the control, respectively, at $10 \mathrm{mM}$ (Table 2). Overall, ferric citrate most significantly suppressed the viability of $L$. yessoense and $C$. pilulifera. To explore treatment concentrations, we used a dose-response curve to de- 

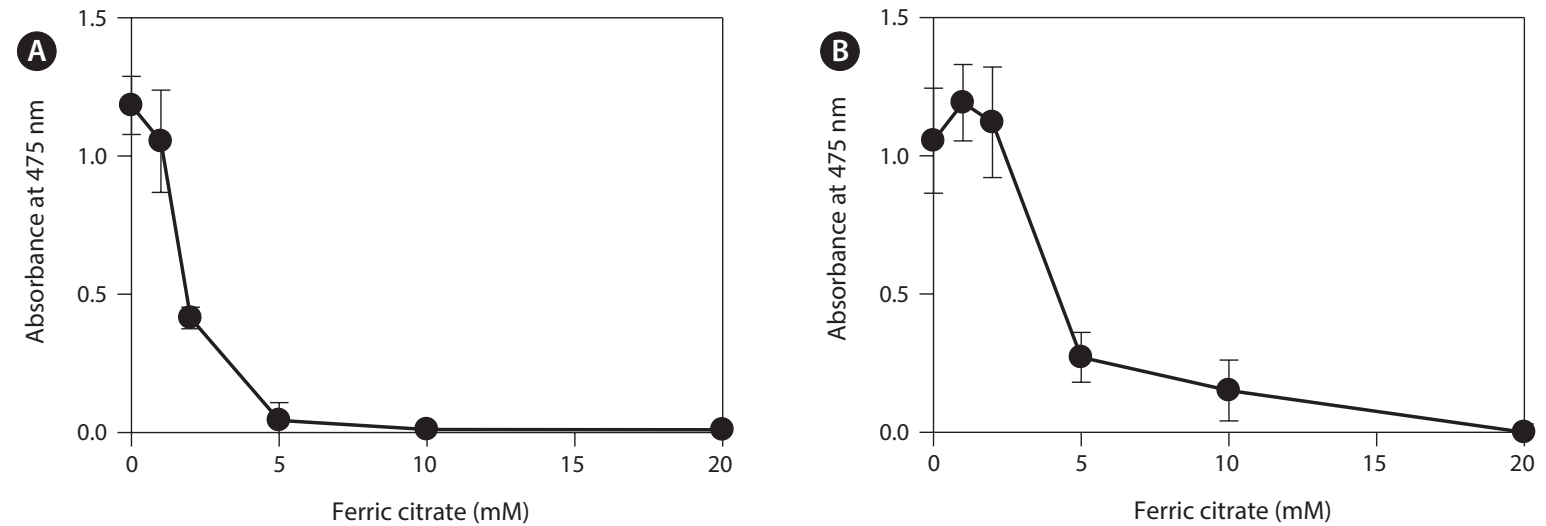

Fig. 1. Effects of ferric citrate on the viability of tissues from the crustose alga Lithophyllum yessoense (A) and articulated alga Corallina pilulifera (B). Viability was measured based on the absorbance at $475 \mathrm{~nm}$; the values are expressed as the mean $\pm \mathrm{SD}$ of at least three independent assays.

Table 1. Effects of calcification inhibitors on the viability of the crustose coralline alga Lithophyllum yessoense

\begin{tabular}{|c|c|c|c|c|}
\hline \multirow[b]{2}{*}{ Calcification inhibitor } & \multicolumn{2}{|c|}{$10 \mathrm{mM}$} & \multicolumn{2}{|c|}{$1 \mathrm{mM}$} \\
\hline & $\begin{array}{c}\text { Absorbance at } \\
\quad 475 \mathrm{~nm}^{\mathrm{a}}\end{array}$ & $\begin{array}{c}\text { Relative } \\
\text { viability }^{\mathrm{b}}(\%)\end{array}$ & $\begin{array}{c}\text { Absorbance at } \\
475 \mathrm{~nm}^{\mathrm{a}}\end{array}$ & $\begin{array}{c}\text { Relative } \\
\text { viability }^{\mathrm{b}}(\%)\end{array}$ \\
\hline \multicolumn{5}{|l|}{ Hydroxyapatite inhibitors } \\
\hline Alendronate & $0.86 \pm 0.18$ & 69 & $1.58 \pm 0.10$ & 127 \\
\hline $\mathrm{AlCl}_{3}$ & $0.83 \pm 0.18$ & 67 & $1.33 \pm 0.15$ & 107 \\
\hline Dichloromethylene diphosphonic acid & $1.27 \pm 0.35$ & 102 & $1.50 \pm 0.06$ & 121 \\
\hline Etidronic acid & $0.91 \pm 0.42$ & 73 & $1.22 \pm 0.29$ & 98 \\
\hline Ferric citrate & $0.02 \pm 0.01$ & $2^{*}$ & $0.94 \pm 0.22$ & 76 \\
\hline $\mathrm{FeCl}_{3}$ & $0.67 \pm 0.15$ & $54^{*}$ & $1.14 \pm 0.38$ & 92 \\
\hline \multicolumn{5}{|l|}{ Bicarbonate channel blocker } \\
\hline 4,4'-Diisothiocyanatostilbene- $2,2^{\prime}$-disulfonic acid & $\mathrm{ND}^{\mathrm{c}}$ & $\mathrm{ND}^{\mathrm{c}}$ & $1.71 \pm 0.31$ & 138 \\
\hline \multicolumn{5}{|l|}{ Carbonic anhydrase inhibitor } \\
\hline Acetazolamide & $0.89 \pm 0.40$ & 72 & $1.18 \pm 0.19$ & 95 \\
\hline
\end{tabular}

The reference culture showed an absorbance of $1.24 \pm 0.14$. The data represent the mean \pm SD $(n \geq 3)$.

${ }^{\mathrm{b}}$ The relative viability $(\%)$ is expressed as $(\mathrm{S} / \mathrm{C}) \times 100$, where $\mathrm{S}$ is absorbance in the presence of the inhibitor and $\mathrm{C}$ is absorbance of the reference.

${ }^{c} \mathrm{ND}$, not determined due to solubility issues.

" $P<0.01$.

Table 2. Effects of calcification inhibitors on the viability of the coralline alga Corallina pilulifera

\begin{tabular}{|c|c|c|c|c|}
\hline \multirow[b]{2}{*}{ Calcification inhibitor } & \multicolumn{2}{|c|}{$10 \mathrm{mM}$} & \multicolumn{2}{|c|}{$1 \mathrm{mM}$} \\
\hline & $\begin{array}{c}\text { Absorbance at } \\
\quad 475 \mathrm{~nm}^{\mathrm{a}}\end{array}$ & $\begin{array}{c}\text { Relative } \\
\text { viability }^{\mathrm{b}}(\%)\end{array}$ & $\begin{array}{c}\text { Absorbance at } \\
\qquad 75 \mathrm{~nm}^{\mathrm{a}}\end{array}$ & $\begin{array}{c}\text { Relative } \\
\text { viability }^{\mathbf{b}}(\%)\end{array}$ \\
\hline \multicolumn{5}{|l|}{ Hydroxyapatite inhibitors } \\
\hline Alendronate & $0.92 \pm 0.08$ & 83 & $1.24 \pm 0.02$ & 112 \\
\hline $\mathrm{AlCl}_{3}$ & $0.22 \pm 0.10^{*}$ & 20 & $1.03 \pm 0.29$ & 93 \\
\hline Dichloromethylene Diphosphonic acid & $0.71 \pm 0.11$ & 64 & $0.88 \pm 0.21$ & 79 \\
\hline Etidronic acid & $0.43 \pm 0.21^{*}$ & 39 & $0.80 \pm 0.15$ & 72 \\
\hline Ferric citrate & $0.17 \pm 0.11^{*}$ & 15 & $0.81 \pm 0.19$ & 73 \\
\hline $\mathrm{FeCl}_{3}$ & $0.32 \pm 0.14^{*}$ & 29 & $1.18 \pm 0.19$ & 96 \\
\hline \multicolumn{5}{|l|}{ Bicarbonate channel blocker } \\
\hline $4,4^{\prime}$-Diisothiocyanatostilbene-2,2'-disulfonic acid & $\mathrm{ND}^{\mathrm{c}}$ & $\mathrm{ND}^{\mathrm{c}}$ & $0.61 \pm 0.19$ & 55 \\
\hline \multicolumn{5}{|l|}{ Carbonic anhydrase inhibitor } \\
\hline Acetazolamide & $0.51 \pm 0.12^{*}$ & 46 & $0.93 \pm 0.23$ & 76 \\
\hline
\end{tabular}

The reference culture showed an absorbance of $1.11 \pm 0.15$. The data represent the mean \pm SD $(n \geq 3)$.

${ }^{b}$ The relative viability $(\%)$ is expressed as $(S / C) \times 100$, where $S$ is absorbance in the presence of the inhibitor and $C$ is absorbance of the reference.

'ND, not determined due to solubility issues.

${ }^{*} P<0.01$. 
termine the concentration resulting in $50 \%$ inhibition $\left(\mathrm{IC}_{50}\right)$ and the minimum concentration resulting in $100 \%$ inhibition (MIC). For ferric citrate against L. yessoense, a typical gradient of viability inhibition ranged sigmoidally with $\mathrm{IC}_{50}$ and MIC values of 1.7 and $10 \mathrm{mM}$, respectively (Fig. 1A). For C. pilulifera, a typical gradient of inhibition showed $\mathrm{IC}_{50}$ and MIC values of 3.8 and $20 \mathrm{mM}$, respectively (Fig. 1B).

\section{Discussion}

Algal whitening can devastate marine forests. However, algal whitening-causing coralline species may be used to prevent fouling by fleshy seaweed. Thus, biomimetic coralline algae may be applicable as an environmentally friendly material for anti-fouling coating treatment. To generate biomimetic coralline algae, it is necessary to include calcification inhibitors in the material to prevent the additional attachment and growth of living coralline species. Calcification is a critical process in plants because calcareous skeletons support and protect the soft parts of organisms, and secreted proteins play major roles in the photosynthetic assimilation of bicarbonate and nutrient acquisition (McConnaughey and Whelan, 1997). To identify potent inhibitors of coralline algal growth, eight commercial calcification inhibitors were compared using TTC assays. Among them, ferric citrate or Fe(III) citrate showed the strongest inhibition against coralline cell viability. Ferric citrate as a hydroxyapatite inhibitor is also known to be a nonprotein-bound iron transporter in plants (Solti et al., 2012) and animals (Baker et al., 1998). Part of the ferric ion undergoes reduction to ferrous iron mediated by ferric chelate reductases (Jeong et al., 2008). Ferrous citrate or Fe(II) citrate induces oxidative damage in mitochondria through lipid peroxidation and alterations in membrane proteins (Castilho et al., 1994). Under natural conditions, iron can be present as divalent or trivalent cations depending on the chemical environment, which makes it a good cofactor for oxidoreductase-type enzymes. Nevertheless, free ferrous ions are dangerous to living organisms as they can catalyze the Fenton reaction and produce reactive radicals (Winterbourn, 1995). Thus, at specific concentrations and in a localized area, ferric citrate may be used to prevent the additional settlement of coralline algae on biomimetic materials or to prevent the blooming of coralline algae.

\section{Acknowledgments}

This work was supported by a National Research Foundation of Korea grant funded by the Korean Government (MEST) (NRF-M1A5A1-2011-0029963).

\section{References}

Agateuma Y, Mateuyama K, Nakata A, Kawai T and Nishikawa N. 1997. Marine algal succession on coralline flats after removal of sea urchins in Suttsu bay on the Japan Sea coast of Hokkaido, Japan. Nippon Suisan Gakkaishi 63, 672-680.

Baker E, Baker SM and Morgan EH. 1998. Characterisation of nontransferrin-bound iron (ferric citrate) uptake by rat hepatocytes in culture. Biochim Biophys Acta 1380, 21-30.

Castilho RF, Meinicke AR, Almeida AM, Hermeslima M and Vercesi AE. 1994. Oxidative damage of mitochondria induced by Fe(II) citrate is potentiated by $\mathrm{Ca}^{2+}$ and includes lipid peroxidation and alterations in membrane proteins. Arch Biochem Biophys 308, $158-163$

Chung HS, Cho KW, Chung KH, Kim JH, Shin JH, Seo YW, Kang JS and Lee IK. 1998. Ecological characteristics of algal whitening in coastal zone of Seogwipo area, Cheju Island. Algae 13, 362-374.

Daume S, Brand-Gardner S and Woelkerling WJ. 1999. Settlement of abalone larvae (Haliotis laevigata Donovan) in response to nongeniculate coralline red algae (Corallinales, Rhodophyta). J Exp Mar Biol Ecol 234, 125-143.

Jeong J, Cohu C, Kerkeb L, Pilon M, Connolly EL and Guerinot ML. 2008. Chloroplast $\mathrm{Fe}(\mathrm{III})$ chelate reductase activity is essential for seedling viability under iron limiting conditions. Proc Natl Acad Sci USA 105, 10619-10624.

Jin HJ, Seo GM, Cho YC, Hwang EK, Sohn CH and Hong YK. 1997. Gelling agents for tissue culture of the seaweed Hizikia fusiformis. J Appl Phycol 9, 489-493.

Johnson CR and Mann KH. 1986. The crustose coralline alga, Phymatolithon Foslie, inhibits the overgrowth of seaweeds without relying on herbivores. J Exp Mar Biol Ecol 96, 127-146.

Kang SE, Park SM, Choi JS, Ahn DH, Kim YD and Hong YK. 2005. Effect of seaweed extracts on the viability of the crustose coralline Lithophyllum yessoense. J Fish Sci Technol 8, 243-246.

Kim JH. 2000. Taxonomy of the Corallinales, Rhodophyta, in Korea. Ph.D. Dissertation, Seoul National University, Seoul, KR.

Kim MJ, Choi JS, Kang SE, Cho JY, Jin HJ, Chun BS and Hong YK. 2004. Multiple allelopathic activity of the crustose coralline alga Lithophyllum yessoense against settlement and germination of seaweed spores. J Appl Phycol 16, 175-179.

Luyen QH, Cho JY, Choi JS, Kang JY, Park NG and Hong YK. 2009. Isolation of algal spore lytic $\mathrm{C} 17$ fatty acid from the crustose coralline seaweed Lithophyllum yessoense. J Appl Phycol 21, 423-427.

Masaki T, Fujita D and Hagen NT. 1984. The surface ultrastructure and epithallium shedding of crustose coralline algae in an Isoyake area of southwestern Hokkaido, Japan. Hydrobiologia 116/117, 218223.

McConnaughey TA and Whelan JF. 1997. Calcification generates protons for nutrient and bicarbonate uptake. Earth-Sci Rev 42, 95-117.

Ohsawa N, Ogata Y, Okada N and Itoh N. 2001. Physiological function of bromoperoxidase in the red marine alga, Corallina pilulifera: production of bromoform as an allelochemical and the simultaneous elimination of hydrogen peroxide. Phytochemistry 58, 683692. 
Park SM, Kang SE, Choi JS, Cho JY, Yoon SJ, Ahn DH and Hong YK. 2006. Viability assay of coralline algae using triphenyltetrazolium chloride. Fish Sci 72, 912-914.

Provasoli L. 1968. Media and prospects for the cultivation of marine algae. In: Cultures and Collections of Algae. Watanabe A and Hattori A, eds. The Japanese Society of Plant Physiologists, Tokyo, JP, pp. 63-75.

Solti A, Kovacs K, Basa B, Vertes A, Sarvari E and Fodor F. 2012. Uptake and incorporation of iron in sugar beet chloroplasts. Plant
Physiol Biochem 52, 91-97.

Suzuki Y, Takabayashi T, Kawaguchi T and Matsunaga K. 1998. Isolation of an allelophatic substance from the crustose coralline algae, Lithophyllum spp., and its effect of on the brown alga, Laminaria religiosa Miyabe (Phaeophyta). J Exp Mar Biol Ecol 225, 69-77.

Tokuda H, Kawashima S, Ohno M and Ogawa H. 1994. Seaweeds of Japan. Midori Shobo Co., Tokyo, JP.

Winterbourn CC. 1995. Toxicity of iron and hydrogen peroxide: the Fenton reaction. Toxicol Lett 82/83, 969-974. 